Article

\title{
Governance and Degrowth. Lessons from the 2008 Financial Crisis in Latvia and Iceland
}

\author{
Åsa Nyblom ${ }^{1, *}$, Karolina Isaksson ${ }^{2,3}{ }^{\circledR}$, Mark Sanctuary ${ }^{1}$, Aurore Fransolet ${ }^{4}$ and Peter Stigson ${ }^{5}$ \\ 1 IVL Swedish Environmental Research Institute, P.O. Box 210 60, SE-100 31 Stockholm, Sweden; \\ mark.sanctuary@ivl.se \\ 2 VTI Swedish National Road and Transport Research Institute, Box 55685, SE-102 15 Stockholm, Sweden; \\ karolina.isaksson@vti.se \\ 3 KTH Urban and regional studies, School of Architecture and the Built Environment, \\ 10044 Stockholm, Sweden \\ 4 Centre for Studies on Sustainable Development (DGES), Université libre de Bruxelles, CP 130/03, \\ Avenue F.D. Roosevelt 50, 1050 Brussels, Belgium; afransol@ulb.ac.be \\ 5 Projektengagemang AB, P.O. Box 47146, 10074 Stockholm, Sweden; peter.stigson@pe.se \\ * Correspondence: asa.nyblom@ivl.se; Tel.: +46-107-886-640
}

Received: 24 January 2019; Accepted: 18 March 2019; Published: 22 March 2019

\begin{abstract}
This paper investigates the role of governance dimensions in socio-economic transitions in line with degrowth, i.e., an equitable downscaling of the economy. Our focus is on experiences from the 2008 economic crisis in Latvia and Iceland. Although these cases are not in themselves examples of degrowth, we see them as important sources of empirical learning from major socio-economical transitions; furthermore, we see crises as possible starting points for future degrowth transitions. This paper applies a governance framework to explore the vast differences in management strategies and crisis outcomes in Latvia and Iceland. In Iceland, public resistance led to a shift in policy measures such that economic inequality and the negative social consequences of the crisis decreased. In Latvia, public resistance existed but had no strong influence. The outcome in Latvia included none of the elements of equitable downscaling found in the case of Iceland. These two cases show how differences in formal institutional arrangements, political culture and societal trust affect different governance dimensions during a time of crisis. The analysis illustrates the importance of institutional and governance dimensions in major socio-economical transitions, and demonstrates how they influence the kind of transition that can be realized.
\end{abstract}

Keywords: degrowth; equitable downscaling; governance; institutions; policy; radical socio-economic transitions

\section{Introduction}

In society today, there is an increasing awareness of the rapid and fundamental changes that will be needed if we are to live within our planetary boundaries and achieve long-term sustainable development [1,2]. The scale of these changes requires not only technological innovation, but also an alteration of norms, values, practices and societal power relations [3-8]. The growing research on degrowth is an example of a discussion that seeks to provide insights into other ways of creating development and welfare- beyond the conventional growth paradigm—by stressing the need for new trajectories, politics and policy approaches [3].

In a broad sense, degrowth can be framed as a formulation of individual and collective goals that can enable long-lasting socio-environmental welfare over generations [5,9]. In more specific terms, degrowth requires equitable downscaling of production and consumption levels in order to ensure a society remains within ecological boundaries, while maintaining social equity [10]. Within 
degrowth research, the current economic paradigm is seen as a cause of resource depletion, climate change, biodiversity loss, social inequalities and so forth [11,12]. In contrast, degrowth advocates a new development agenda based on ideals of welfare, progress and quality of life.

Today, there is extensive literature on degrowth as a concept and idea, which examines what a degrowth society is, and what it is not $[4,5,13,14]$. The literature includes descriptions and analyses of the vast systemic differences between how a degrowth society functions and the operation of today's growth economy-based societies. It also includes studies of specific initiatives such as community food production, local currencies, and recycling and reuse initiatives that hold a fundamental social critique in their way of functioning, and that express a radically different logic for how society and the economy could be organized [15-17]. However, concrete, real-world empirical examples are still limited in scale and number, and there is a lack of empirical studies on the specific institutional conditions and governance arrangements that can support a wider shift away from economic growth [18-23].

This paper provides an empirical analysis of the institutional dimensions of large socio-economical transitions, with a specific focus on the role of governance. In the absence of empirical examples of full-scale degrowth, our research strategy explores Iceland's and Latvia's responses to the 2008 economic recession. While both countries suffered severely under the crisis, they responded to the crisis in distinctly different ways. In addition, the outcomes of the crisis were distinctly different in Iceland and Latvia according to parameters related to the definition of degrowth as "equitable downscaling," which makes them interesting as contrasting cases. The differences in outcome can be illustrated using indicators based on the work of Kallis [4], who suggests welfare/equality indicators and throughput-related indicators as examples of variables that can capture aspects or elements of equitable degrowth. There is no consensus on a set of indicators that adequately capture degrowth as a policy objective. Rather, we present a selection of variables that capture aspects of equitable downscaling, while acknowledging that our selection is not comprehensive. In terms of welfare/equality indicators, while unemployment rose in both countries, it rose more sharply and to much higher levels in Latvia. Unemployment (as a percentage of total labor force) peaked in 2010 at 7.5\% in Iceland and 19.5\% in Latvia. Similarly, emigration from both Iceland and Latvia increased with the crisis [24,25]. Income inequality (measured by the Gini coefficient) decreased in both countries after the crisis; however, the decrease in inequality was much sharper in Iceland, where the Gini fell by around six index points between 2008 and 2010, compared with a fall of two index points in Latvia (Figure 1). In terms of throughput-related indicators, Iceland's $\mathrm{CO}_{2}$ emissions per capita fell sharply by $13 \%$ between 2007 and 2009 as a result of the crisis, whereas Latvia's $\mathrm{CO}_{2}$ emissions per capita remained essentially unaffected [26]. These distinct emission trajectories during the crisis reflect the different industrial structures of the two countries. The Latvian economy is more dominated by the service sector than Iceland and is therefore less $\mathrm{CO}_{2}$-intensive. On these grounds, Iceland appears to have had an outcome of the economic crisis in which more elements of degrowth can be detected, in comparison with Latvia.

Although economic recessions are not in themselves examples of degrowth, they can be seen as possible starting points for such a transition (c.f. Section 2.5. An economic crisis provides an opportunity to analyze the role of governance in a situation of economic transition. The purpose of this paper is to investigate the role of institutional factors and governance dimensions in large socio-economical transitions. In particular, we want to explore their role in relation to transitions towards an equitable downscaling of the economy. In this study, we focus on three specific aspects of the two cases: the framing of the problem; the goals and measures adopted to handle the crisis; and the actors involved, including how they were involved in the process of crisis management and societal transformation (i.e., the degree of centralized vs. dispersed authority).

The role of institutions and governance in a transition to a degrowth society is an under-researched issue in the degrowth literature. A handful of studies have highlighted the need to abandon or at least bring about substantial change in the institutional structures of the growth economy $[19,20]$. Other studies have noted that it is difficult to gain broad political support for a new type of policy agenda that endorses degrowth in practice $[13,18,23,27]$. In a recent study, Buch-Hansen [21] explored what it 
would take for a degrowth paradigm shift to take place, and identified four prerequisites: a deep crisis; the presence of an alternative political project; a comprehensive coalition of social forces promoting the project through political struggles; and broad-based public consent. Buch-Hansen concluded that only the first two prerequisites are adequately fulfilled intoday's society.

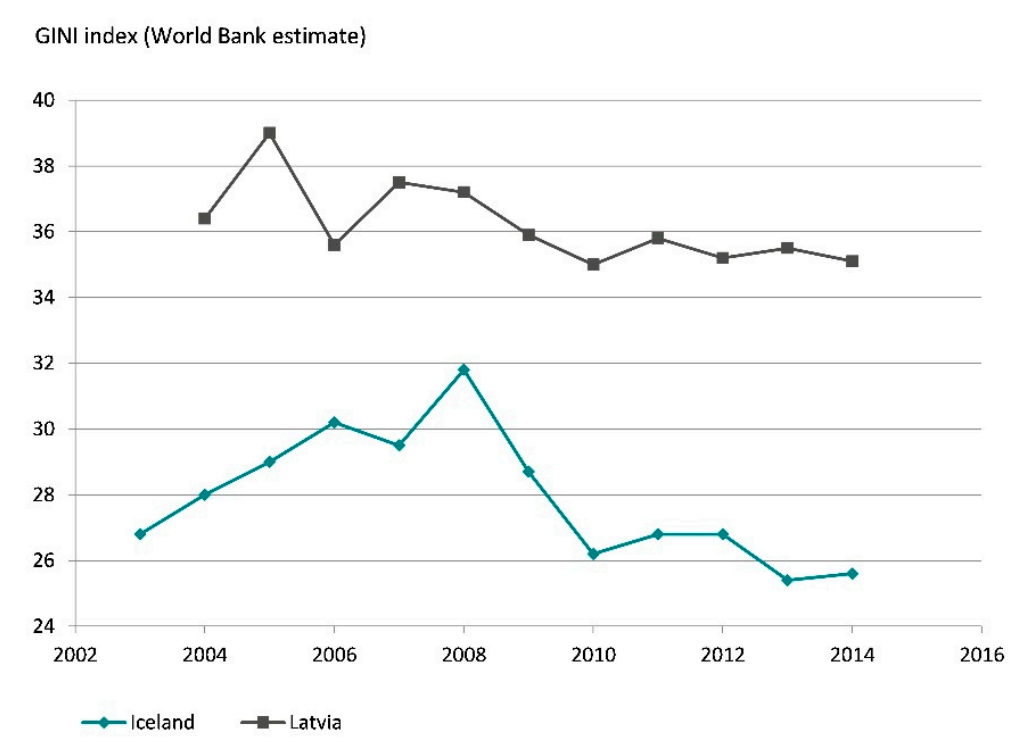

Source: World Bank Data

Figure 1. Evolution of the Gini coefficient (measuring income inequalities) before, during and after the 2008 financial crisis [26].

On the theme of institutional and socio-cultural barriers for societal degrowth transitions/ paradigm shifts, a growing number of studies have focused on the close ties between economic growth and the welfare state, and the challenges of implementing new types of policies that can combine an ambitious climate policy with distributive features to provide social equity [28-31]. For example, Büchs and Koch [32] have pointed to the deeply structural property of economic growth for Western societies post World War II, and to the fundamental challenge of transforming socio-economic systems, institutions and culturally held values in tandem with a (fast enough) degrowth transition. If the systems, institutions and values are not simultaneously changed with the transition, a rapid societal transition is prone to cause severe social conflicts and have a negative effect on wellbeing. Few scholars have empirically researched institutional or governance factors in relation to degrowth transitions. One scholar to do so is Joutsenvirta [23], who studied the struggle between Finnish time-banking activists and tax authorities. Her analysis sheds light on the ways in which existing institutions resist or serve as barriers to change, and also enhances the understanding of the opposing strategies that work to advance new visions and transform society. Buhr et al. [33] have studied degrowth policies in a Swedish local policy context. Their study clarified the importance of discursive categories, networks and arenas where degrowth-related ideas can be discussed and explored. They also showed how opportunities to diverge from conventional development ideas are constrained by prevailing norms, values and visions for the future.

The outline of this paper is as follows: the next section describes the materials and methods, and includes a brief discussion on the theoretical framework, which leads to three research questions. The results section then follows, in which we present the case studies of Iceland and Latvia, and explore the three research questions with the help of the theoretical framework. The paper ends with a discussion and a concluding section in which the findings are discussed in relation to our ambition to contribute to existing knowledge on the role of institutional factors and governance dimensions in degrowth transitions. 


\section{Materials and Methods}

\subsection{Analyzing Governance}

In our work, we define governance broadly as "the practices through which societies are governed" [34], which means that we focus on processes and activities that aim to guide, steer or manage societal development [35]. More specifically, we use the term governance to refer to different types of "political steering involving public and private actors, including traditional modes of government and different types of steering from hierarchical imposition to sheer information measures" [36] (p. 185, in [37]). We apply governance as an analytical framework in order to explore how steering is carried out in practice [37-42]. In doing so, we find the well-known distinction between policy, politics and polity to be a useful way of structuring different dimensions of governance [34,37].

The term policy relates to policy content and questions regarding strategies or steering instruments that are implemented to reach a certain goal. Within this dimension, we will also include issues related to how the crisis is framed, since framings and problem definitions are well-known and important aspects of policy formulation $[34,43]$. Politics relates to the political process, with a focus on actors and power relations. For example, how are different interests balanced in the shaping of collective action? [34] The term polity relates to questions about institutional structures. For example, polity includes analyses of the degree to which interactions between actors involved in a process follow a hierarchical structure, versus being more spread out and thus resembling a market. Polity may also include questions about the formal degree of institutionalization and to what extent authority is centralized or dispersed [37]. In general, governance is to be understood as a dynamic interplay between these three dimensions, each of which refers to aspects of vital importance in the practice of governing [34,37].

\subsection{Research Questions}

We used the three dimensions of governance as a point of departure to develop questions to guide the analysis. In our work, we explore (1) how the crisis was defined and framed, and what goals, strategies and measures were developed to meet it; (2) who the key actors were and the power relations between them, with a specific focus on the balance between different interests and concerns; and (3) to what extent the situations were managed through a top-down hierarchical structure, and if authority was centralized or more dispersed.

\subsection{Materials}

This study builds on secondary literature about the crisis and its management in Latvia and Iceland. There have been many publications about these two countries during the years following the 2008 economic crisis. Instead of making a comprehensive compilation of a large number of articles, we chose to select a limited number of texts containing more details and substantive information about the processes, goals and strategies, and key actors in each case. In total, we built our analysis on around 10 to 15 articles from each country. Most of these articles were academic papers from peer-reviewed journals, but a few were books, chapters or newspaper articles.

\subsection{A Qualitative Case Study Approach}

We studied governance using a qualitative case study approach. The basic idea of qualitative case study methodology is that a close analysis of one or a few well-chosen cases can provide knowledge of wider phenomena. Purposeful sampling [44] was used to gain cases related to our research question that were as information-rich as possible. Latvia and Iceland can be described as extreme cases [45], as both were particularly hard hit by the financial crisis. Since large problems call for strong action and trigger a great deal of public attention, it was thus highly probable that these two cases would entail the kind of strategies, processes and actions we wanted to study in exploring the role of institutional features and governance dimensions in the equitable downscaling of the economy. By choosing 
extreme cases that have gained scientific and media interest, we could be sure of gaining access to relevant information through secondary literature (see below), which was a practical selection criterion for the study. To ensure that the cases could yield data on our specific research question that was as rich as possible, we chose two cases among which the outcome of the crisis for one of them (Iceland) has proven to be more in line with the term "equitable downscaling" than for the other.

Due to its reliance on secondary literature and its limited size and scope, this study cannot draw clear conclusions about causal relationships between governance dimensions and the outcomes of the crisis. Governance is an important factor, but there are other possible explanations for the differences between the two countries that could be explored in further research. However, the selection of one case that contains elements of equitable downscaling, and another case that does not, makes it possible to explore governance dimensions as a specific and important aspect of crisis management. By exploring these two cases from a governance perspective, this paper contributes new perspectives on possible links between governance and degrowth transitions, and provides a richer understanding of the role of institutional factors. The results of our analysis can, in turn, form the basis for new and more specific questions to be explored in further studies.

\subsection{Economic Crisis Versus Degrowth}

A specific difficulty in research on degrowth is related to the lack of empirical examples to learn from. Thus, the emerging research on governance and institutional conditions for transition towards degrowth often draws from small-scale initiatives. Since transitions are always broadly situated and context-dependent, however, it is important to empirically study large-scale societal transitions in different institutional and governance contexts as well.

In the literature, degrowth as an objective is put forward as an orderly and voluntary course of development that builds on other ideas of wellbeing and prosperity than those that can be represented by economic recessions [5]. Thus, degrowth is not the same as a financial crisis, as the latter is not chosen voluntarily. Nevertheless, economic crises are not irrelevant to degrowth, and a historical crisis can serve as a trial run - or at least a starting point-for a change of the economic system [27]. Buch-Hansen [21] even suggests that a crisis is a prerequisite for a degrowth paradigm shift. An economic crisis can also be seen as an opportunity that can facilitate degrowth initiatives. New organizations and initiatives have been seen to arise due to an economic crisis, when conventional institutions fail to secure the basic needs of people in countries such as Argentina, Greece or Catalonia [5]. This article takes the stance that even if economic recessions and crises are not in themselves examples of degrowth, they can still provide important insights into how degrowth can be realized, by making it possible to study empirically the role of institutional and governance dimensions in socio-economical transitions related to a downscaling of the economy. We consider empirical studies to be of great importance for complementing the current literature, which is either purely based in theory or based on empirical studies of small-scale initiatives.

\section{Results}

In this section, the two cases of Latvia and Iceland are presented and analyzed with the help of the governance framework. The structure of the two case studies is as follows. First, we provide a brief introduction to the country and its historical, political and social context. Second, we give an overview of how the economic crisis affected the country, as well as a general description of the course of events in the management process. Finally, we perform an analysis of the governance dimensions extracted from the policy-politics-polity framework.

\subsection{The Case of Latvia}

Latvia is a former Soviet republic located on the eastern shore of the Baltic Sea. It has approximately two million inhabitants. Together with its Baltic neighbors, Latvia became a member of the European Union (EU) in 2004. Since 2014, Latvia has been a member of the Eurozone. 
After Latvia joined the EU, the country experienced rapid economic growth. Latvia, Estonia and Lithuania were described as "poster children for the benefits of economic liberalization and integration with the West" [46] (p. 16). Growth was in the double digits and salaries rose sharply in the years following EU membership. The main driving forces of this growth were high consumption and investments in real estate, along with a great inflow of cheap credit from Nordic banks. Government spending grew significantly during this period, and at a higher speed than the growth in GDP. Expenditure was dominated by maintenance costs, and wages increased by more than $20 \%$ annually $[46,47]$.

Today, Latvia is described as a liberal economy with rather low levels of social security [48,49]. According to the World Bank classification, Latvia is on the cusp of becoming an upper-middle-income and high-income country [50]. Just over $26 \%$ of Latvia's inhabitants are of Russian origin, and this divide has played-and still plays—a significant role in Latvian politics $[46,48]$. The political situation in post-Soviet Latvia has often been volatile. Corruption and strong ties between politicians and business have played a role in Latvian society and politics for a long time $[48,51,52]$. The political influence of so-called oligarchs-that is, successful business leaders who are reputedly tied to corruption-and the weak capacity for effective government have led to low political trust $[46,53]$. Latvian voters tend to trust European institutions more than their own [46].

\subsubsection{Overview of the Crisis and Key Events}

Latvia was one of the first countries affected by the 2008 economic crisis [54], and was also one of the most seriously affected [50]. Growth had already started to slow down early in 2008, and when Lehman Brothers collapsed in September 2008, the country was plunged into financial crisis. This event brought about an international liquidity freeze that blocked Latvia's access to global financial markets, which in turn led to the bankruptcy of Parex Bank, the leading national bank [54]. The crisis caused a sharp economic downturn: Latvia's GDP fell by approximately $23 \%$ [50] and the country had to call in the International Monetary Fund (IMF) and the European Commission for emergency financial aid $[47,54]$. The IMF led the negotiations with a view of preparing and financing an international loan package for Latvia, leading to a series of strict recommendations that aimed to get the immediate liquidity crisis under control and to ensure long-term external stability, while maintaining the exchange rate peg [54]. The decision not to devalue the currency but instead, through an austerity policy, aim for an "internal devaluation" was contested by many economists-also within the IMF-who warned of severe social consequences. However, avoiding a formal devaluation was a key issue for the Latvian government, which was aiming for quick adoption of the Euro [24,47,50,51,54].

In the end, the IMF and the European Commission controlled the implementation of the internal devaluation crisis-management strategy, which rapidly led to improved economic stability and the recovery of GDP growth in Latvia. Many actors have called this a "success story" [47,50,54,55]. However, other voices have questioned the strategy due to its severe social consequences $[47,50]$.

\subsubsection{Framing and Policy Formulation}

When the crisis hit Latvia, international actors such as the EU Commission, the IMF and nations with interests in Latvia's economy perceived the Latvian economic downfall as potentially threatening to the economic stability of neighboring countries and throughout Europe. According to Hilmarsson [50] (p. 3): "EU interests feared the effects of a large depreciation on the banking sector in the other Baltic countries and the Scandinavian countries that could then spill over to other EU member countries."

This initial framing of the crisis was important, not least in relation to the fact that the Latvian government had long held the ambition to become a member of the Eurozone. This membership was perceived as a way of diminishing the perceived threat of Russia, and strengthening Latvian independence in this sense [48]. In other words, the crisis was not just a problem in itself; it was also a threat to a more long-term strategy of Latvian empowerment and integration with other EU 
members [50,51,54]. According to a rich empirical study by Eihmanis [48], the Latvian government also saw the economic crisis-and especially the external constraints posed by the IMF and the EU Commission - as a means to push through tough political reforms that had already been planned, but that had been politically impossible to implement before the crisis. Eihmanis describes the situation as a case of so-called "governing by external constraint" [48] (p. 237; see also [54])—that is, using external forces as an impetus to pursue preferred policies.

As has been noted in several earlier works, the explicit aim of the Latvian crisis-management strategy was to reduce the budget deficit, enhance competitiveness and restore (through a resumption of economic growth) international trust in the country $[47,51,56]$. The strategy comprised various policy instruments to reduce public expenditure on the one hand, and raise revenue on the other hand. The measures to reduce expenditure-which according to Dovladbekova [47] were among the most severe in Europe-included a reduction of wages in the public sector by around $26 \%$ between 2009 and 2010 , a reduction of staff in state institutions, the closing of half of the 75 government agencies, cuts in the health and education system, a decrease in public transport subsidies, and a reduction of pensions and maternity pay $[47-49,54,57]$. Revenue-raising measures consisted of the introduction of new taxes; increases in the rates of personal income tax, value-added tax (VAT), property tax and vehicle taxes; and an increase in the excise duties for energy, tobacco, coffee, alcohol and other beverages $[49,54]$.

Previous research has indicated that the Latvian government voluntarily set more ambitious fiscal policy targets than were required by the EU and IMF frameworks. Hence, Latvia's fiscal policy during the crisis has been called a "chain of overachievements" [48] (p. 237). Moreover, the Latvian government did not use all of the fiscal spending options allowed by the EU and IMF frameworks; rather than using unexpected windfall revenue to increase funding for labor market policies and social safety-net measures, the government chose to concentrate on early payback of the bailout loans. According to Blyth [58] (p. 236 in [48]), the government framed austerity as "virtuous pain after the immoral party" during the massive internal devaluation that followed the economic crisis, and thus constructed a new ethos of avoiding spending at any cost.

Perceptions of the crisis among the Latvian public have not been discussed in detail in the previous works this paper is built upon. However, it is well-known that there was a wide dissatisfaction with the crisis-management strategy. In the 2009 Eurobarometer, $97 \%$ of the respondents said they thought that "things in Latvia are going in the wrong direction" [59] (p. 4), mostly due to "the country's economic situation and people's dissatisfaction with the government's activities and decisions as regards reducing the budget deficit" [59].

\subsubsection{The Politics Dimension}

In the politics dimension, the case of Latvia provides an example of a situation with a strong focus on the relation between and interplay with (state and non-state) actors beyond the country's own national borders. The process of preparing a loan package, which was led by IMF, involved the European Commission, the European Central Bank, the World Bank, the European Bank for Reconstruction and Development, the Swedish Ministry of Finance, the Swedish Riksbank and other Nordic governments [54]. In the end, Latvia received commitments of credit from the IMF, EU, the European Bank for Reconstruction and Development (EBRD), the World Bank, several Nordic countries, the Czech Republic, Poland and Estonia [49,50,54].

The EU and IMF monitored the budget consolidation process closely, watching over the fulfilment of EU frameworks and bailout loan conditionality. On the one hand, the EU Commission endorsed the excessive fiscal policies and overachievement of the Latvian government, "as it helped to securitize against uncertainty" [48] (p. 239). On the other hand, the Commission was worried about the social costs of the implemented fiscal consolidation measures. The Commission emphasized repeatedly that more resources had to be allocated to social needs and measures to reduce unemployment; however, it found that the Latvian government did not listen and instead prioritized "getting better budget numbers" [48] (p. 239). 
On the national scale, previous literature reports that the Latvian public suffered from the harsh austerity measures that were implemented. On 13 January 2009, a large public demonstration was organized in Riga to protest against how the government was dealing with the crisis. Around 10,000 people participated in these public protests, although street protests are otherwise very uncommon in Latvia [60]. Intended as a peaceful protest to ask the president to dismiss parliament, it turned into a riot $[51,60]$. The protests did not lead to any immediate results; in terms of power, we note that the citizens' perspectives had no substantial influence on the governance process.

Previous literature does not, unfortunately, contain any detailed information about the internal dynamics of Latvian politics during the crisis. It has been reported that the Latvian government consulted social partners such as employers and trade unions, who opposed the proposed policy programme--but without success [47,60]. Åslund and Dombrovskis [54] have given a slightly different picture, stating that key social partners were on board with the government proposals at the critical time, but later regretted their agreement [54] (p. 78). In any case, the prime minister resigned in February 2009 due to a lack of cooperation from the coalition members [51,60]. A new prime minister, Valdis Dombrovskis, was elected and formed an unsteady coalition that continued the implementation of austerity measures. In the end, a large percentage of the Latvian population "voted with their feet" and simply emigrated from the country during the crisis. $[47,60]$.

\subsubsection{The Polity Dimension}

The polity dimension is related to institutional frameworks and structures, and to the kinds of rationale that shape interactions between actors. As implied above, the key actors involved in the management of the Latvian crisis were the Latvian government, organizations such as the IMF, EU, and EBRD, and foreign countries with financial interests in Latvia. The Latvian public and civil society organizations participated in the framing of - or the decisions on how to tackle-the economic crisis to a much lesser extent. Altogether, the design and implementation of the Latvian austerity-focused crisis-management strategy was highly centralized and top-down. The limited influence of public opinion and stakeholder groups is partly explained by the weak tradition of NGOs and of civil protests in Latvia [61]. Today's Latvia has no tradition of labor activism, and the leftist political forces that have opposed austerity elsewhere in Europe are largely absent [62]. Social mobilization in Latvia normally happens through more individual means, such as litigation, petitions and letters to institutions and MPs [60]. Bideleux [63] has argued that present-day adult populations in European post-communist states are generally disinclined to join political parties, social movements and public protests, and that the normal public response to an economic crisis is to "grit their teeth, keep their heads down and work even harder than before" while waiting for the crisis to blow over.

\subsection{The Case of Iceland}

Iceland is a small island nation in the northern Atlantic, with just under 350,000 inhabitants. After a long period of Danish rule, Iceland gained independence in 1944. At this time, Iceland was one of the poorest countries of Western Europe; however, by the early 1980s, it had turned into a prosperous, industrialized and highly affluent Nordic welfare democracy with a high level of social security [64-66]. According to the World Bank classification, Iceland is a high-income OECD country [50].

Iceland is not a member of the EU, although it has been part of the European Economic Area Zone (EEA) since 1995. From the mid-1990s onwards, public policy in Iceland was significantly influenced by a neo-liberal economic agenda with a strong belief in market forces and privatization $[65,67]$. Among other things, this led to the privatization and fast expansion of the Icelandic banks, which developed a lending policy allowing Icelanders to easily borrow money for consumption. The Icelandic banks also established themselves on the international stage; in 2003, Iceland increased its prime rate to $15 \%$ to try to attract international currency investments [68].

By tradition, Iceland has been characterized by close social relations and collectively held values emphasizing egalitarianism, nationalism, hard work and sobriety $[64,66]$. Previous research has 
noted how the implementation of the neo-liberal economic agenda in the mid-1990s and early 2000s was reinforced by an "official discourse on entrepreneurship and independence-seen as inherently Icelandic characteristics" [67] (p. 345). In practice, the neo-liberal agenda led to a considerably higher degree of income and wealth inequality than had been the case before [68].

The corruption level in Iceland is comparatively low [52]. In the aftermath of the economic crisis, however, the close relationship between the ruling political parties and the economic elites was brought forward as an important explanation of the high economic risks that were taken in the Icelandic economy during the 1990s [66].

\subsubsection{Overview of the Crisis and Key Events}

One of the key issues that has been much referred to in literature on the Icelandic economic crisis is the rapid expansion, privatization and internationalization of the Icelandic banks after the mid-1990s, and especially the type of economic policy the banks implemented, which included generous lending for consumption. Another well-known issue was the "Icesave" account-namely, an Internet-based easy-access saving account held by the reputable bank Landsbanki, which offered high interest rates for British and Dutch customers [69].

In 2008, the balance sheet of the three major Icelandic banks-Kaupthing, Glitnir and Landsbanki-amounted to 14 times the national GDP [70,71] and the Icelandic banks had amassed considerable debts. After the collapse of Lehman Brothers in September 2008, the Icelandic banks lost all access to credit on the market and could no longer finance themselves [69,71]. This led to a rapid crash in Iceland's currency and a large GDP decline of approximately 10\% [50]. The large proportion of mortgages and loans in foreign currencies or indexed to inflation in the Icelandic banking system caused household and corporate debt to skyrocket, and made it impossible for many households and corporations to pay the rising interest rates $[69,72,73]$.

Iceland's method of dealing with the external debts of the banks was the subject of great controversy, with many unexpected events that led to both diplomatic problems and popular uprisings. Icelandic citizens expressed strong dissatisfaction with the way in which politicians, banks and public authorities had been managing their economy. Massive street protests, known as the "pots-and-pans revolution," led to the resignation of the center-right coalition government and the election of a new center-left coalition government that came to power in early 2009 [69]. Public referendums were held in both 2010 and 2011 about how to move on with the reimbursements to Great Britain and the Netherlands (broadly known as the "Icesave bills"). Both times, the majority of the Icelandic population voted against the bills. In the end, Iceland let its banks collapse and did not reimburse the foreign investors [50,69-71].

During this time of diplomatic difficulty and public criticism and rebellion following the crisis, the Icelandic government introduced several measures-which complemented capital controls-to balance the economy. A key priority was to preserve the Nordic welfare model and shield low-income groups $[50,66,70]$. The central bank also implemented monetary stimulus measures to steer inflation close to target [70]. To revive the economy, Iceland mainly relied on its natural resources by developing the fishing, tourism and energy sectors [74]. In the end, Iceland was financially supported by the Faroe Islands, Poland, and Russia, as well as, later, by Scandinavian countries that had initially been reluctant to intervene $[50,74]$

\subsubsection{Framing and Policy Formulation}

The Icelandic center-right coalition government that was in office when the crisis hit initially framed the economic crisis as "bad weather" - that is, as a problem caused by external global forces, of which Iceland was one of many victims [64]. That government viewed the situation as primarily a banking, currency and economic crisis [65]. It claimed that the authorities could not be held accountable for the actions of private banks operating in international markets, and that the government instead 
needed public support to rescue the domestic banking system and handle the acute currency crisis and the liability claims coming from abroad $[64,69]$.

International actors such as the IMF framed the economic crisis in Iceland as severe [65]. When it turned out that the Icelandic state could not bail out the banks and instead decided to rescue only domestic operations-while allowing foreign operations to become insolvent and taking measures to prevent foreign capital from flowing out of the country [64] - the situation was no longer just an economic crisis but also a diplomatic one. International relations became strained, especially with Great Britain and the Netherlands, who demanded a reimbursement of their citizens' lost savings in the "Icesave accounts" [69,75]. The UK deployed anti-terrorist legislation in October 2008 to freeze the assets from the collapsed Icelandic banks in the UK. Doing so placed Iceland on the UK's list of terrorist groups, alongside Burma, North Korea and Al-Qaida [64,76]. When Iceland applied for IMF loans to handle the immediate effects of the crisis, the IMF sided with the Netherlands and the UK, and demanded that Iceland should compensate for foreign losses [64,71]. This was also the view of the Nordic countries approached by Iceland for financial support in the acute currency crisis $[64,69]$. The countries affected by the collapse of the Icelandic banks saw the Icelandic state's decision to only rescue the banks' national operations as hostile and untrustworthy.

In contrast, a large proportion of the Icelandic people challenged the framing of the crisis as something that primarily hit the country from outside, and claimed that it was the political leadership that had created the crisis through incompetence, corruption and blind faith in market forces $[64,69]$. This perception characterized the "pots-and-pans revolution," which eventually brought down the sitting government. The left-center government that took power in February 2009 responded to the public framing of the crisis, and had a clearly stated focus on sheltering lower and middle-income groups from severe consequences [65]. Welfare expenditure cuts were made carefully, with specific measures directed at those with low incomes. Increased taxes primarily affected higher income groups, including those that had gained the most during the boom years before the crisis $[65,66]$. The government also introduced various debt-relief programmes, which were generally targeted at households in great need [65].

However, when taking over the IMF and Icesave negotiations in early 2009, the new government also accepted the view expressed by IMF and others-that Iceland should compensate the Dutch and British losses [64]. The first proposal for a reimbursement strategy, the so-called "Icesave 1," was a deal to reimburse an amount equivalent to one third of Iceland's GDP, while benefiting from a low rate and a long period of repayment. The Icesave 1 bill was accepted by the Icelandic parliament in September 2009 but was rejected by the British and Dutch governments due to disagreements about the terms, such as how long the payment requirements should apply for. The Icelandic government developed another proposal, "Icesave 2," which met the demands of the UK and Dutch governments. Icesave 2 was accepted by the Icelandic parliament in December 2009. However, public protesters saw it as unfair to have the Icelandic public pay for private debt [69], and wrote a petition that received 60,000 signatures (almost $20 \%$ of the whole population) in which they protested against the Icesave bill and called for a referendum. The president passed the issue on to a referendum, held in March 2010. As a result, an overwhelming majority of Icelandic citizens ( $93 \%$ of voters) rejected the proposal. A new draft agreement was then prepared, voted on in another referendum in April 2011, and rejected as well by the citizens [67]. In the end, Iceland let its banks collapse and did not reimburse the foreign investors [50,69-71].

\subsubsection{The Politics Dimension}

In the politics dimension, the case of Iceland provides a fascinating illustration of a political process in which the state and its representatives tried to balance the demands from Icelandic citizens, on the one hand, with the demands from external actors, on the other. The Icesave bills were a direct consequence of the requirements from the IMF and other potential lenders that Iceland should take responsibility for economic losses in other countries. At the same time, the left-center government that 
came to power in early 2009 had the key task of sheltering lower income groups from the consequences of the crisis. This was mirrored in the design of the national economic measures, as mentioned above. Still, the majority of the citizens refused to accept the Icesave programme, and the referendums led to defeat for the proposed Icesave programmes [64]. In the end, the story of Iceland reflects a process in which the voices of Icelandic citizens eventually prevailed over the concern for international relations and savers from abroad.

\subsubsection{The Polity Dimension}

The steering mode of the crisis-management strategy in Iceland can be categorized as top-down at the start, but then shifting towards bottom-up as a result of civic mobilization and intervention in the steering mode in the later phases of the crisis. The public protests succeeded in bringing down the sitting government, reframing the crisis (as originating not from external forces but from internal problems of too-extreme neo-liberal politics and corrupt decision-makers), bringing the Icesave bills to two referendums, and then rejecting them. The level of participation in the public protests was exceptionally high, even though prior to the 2008 economic crisis, Iceland had almost no tradition of mass protest: about $25 \%$ of adult Icelandic citizens participated in the public protests, and a substantial majority supported them, according to Bernburg [64].

\section{Discussion and Conclusions}

The ambition of this paper is to provide empirically grounded knowledge about the role of institutions and governance dimensions in radical societal change, with a focus on socio-economical transitions towards degrowth. As discussed at the onset of the paper, neither Iceland nor Latvia intentionally strove for degrowth, and the socio-economic transitions following the crisis were both involuntary and took place within a growth paradigm (i.e., were aimed at future regrowth). In Iceland, however, the management and outcome of the crisis had some elements of degrowth (equitable downscaling), whereas the Latvian situation contained no such elements. In this section, we summarize and discuss the main findings from the analysis, with a focus on the aspects of governance that appear to be of particular importance for the differences between the two cases.

First, regarding the policy dimension, we note the importance of how the crisis was framed and how this became instrumental in deciding which related goals and measures were given centrality in the management of the crisis. There were significant differences between the two countries in this respect. In Latvia, the crisis was defined as an unfortunate event that hit the country hard from the outside. This blow struck just as Latvia was taking its final step towards entering the Economic and Monetary Union (EMU), which was an important milestone in the process of leaving its Soviet past, and becoming an independent, economically liberal European country. Entering the EMU was kept as a priority during the crisis, and strongly influenced the chosen path of internal devaluation as a crisis-management strategy, although this came with a high social price. In Iceland, there was instead a struggle between two different interpretations of the crisis. At first, the crisis was framed similarly as in Latvia-that is, as being caused by global forces, with Iceland just one of many (innocent) victims. Eventually, however, an alternative view developed. According to this alternative framing of the crisis, Iceland was not an innocent victim of global forces. Instead, the crisis was viewed as a consequence of a blind faith in market forces and of irresponsibility, incompetence and corruption among the ruling elites. This reframing of the crisis led to new suggestions on how to handle the situation, and to alternative goals and priorities. The political leadership was replaced, and issues of welfare and internal distribution politics became more influential.

Regarding the politics dimension, this study clarifies a difference in power relations between the two countries. In Latvia, the main emphasis was put on the relation and interplay with the IMF, EU and neighboring countries. In Iceland, as a contrast, the state tried to balance its citizens' demands with those of external actors. Eventually, however, public protests and the alternative framing of the crisis paved the way for a shift in power balance, causing the demands of citizens to become much more 
influential. This leads us to the polity dimension, where Latvia represents a top-down hierarchical structure in which the initial power relations prevailed or were strengthened. In the case of Iceland, authority was much more dispersed; in the end, there was a change in power relations.

Definite answers to why the public and its framing of the crisis became much more influential in Iceland than in Latvia cannot be given in this study, but wider institutional and historical differences between the two countries certainly played a role. The post-Soviet legacy in Latvia was influential in strengthening the focus on the IMF and EU. The lack of alternatives that were not tied to Russia, and a culture influenced by the post-Soviet transition, made many Latvians inclined to seek individual solutions rather than continue protesting, when protesting seemed to have no result. In contrast, the public protests in Iceland endured, leading to referendums and to new crisis-management strategies and goals. Here, it should be noted that Iceland eventually succeeded in acquiring financial support from neighboring Nordic countries, although these countries were initially unsupportive. It was probably possible for Iceland to get this support in the end due to historically close bonds, prior cooperation and interdependence among the Nordic countries.

This exploration of experiences from Latvia and Iceland resulted in several insights regarding governance and degrowth. However, as stated at the beginning of this paper, these cases are not examples of a deliberate degrowth-oriented policy agenda. This is a weakness in our work, as a voluntary transition to degrowth might follow a different pathway than what was found in this study. However, since crises such as the 2008 economic recession are likely starting points-or even prerequisites-for degrowth transitions/paradigm shifts to occur, we argue that an empirical analysis of socio-economic transitions such as those in Iceland and Latvia can grant important insights to bring to the theoretical discussions of degrowth transitions. We argue that the lessons learned from this study provide a basis for drawing at least tentative conclusions about the governance dimensions of importance in enacting radical socio-economic change in line with degrowth.

First, this study confirms a central argument within governance theory: that governance needs to be understood and analyzed in an integrated way, with a focus on the relations between policy, politics and polity dimensions. Second, it is evident that issues related to governance and institutional configurations cannot be clearly separated from their specific contexts; they are shaped by past and present history. As discussed above, different historical and cultural aspects became influential in the framings and actor constellations that gained influence on crisis management and in how goals of social equality were prioritized.

A third general outcome of this study is related to the work of Buch-Hanssen (2018), who has identified necessary prerequisites for socio-economic paradigm shifts [21] (see Section 1). The case of Iceland illustrates a situation that comes close to Buch-Hansens's theory. In this case, a public uprising (the "pots-and-pans revolution") generated a comprehensive coalition of forces mobilizing for an alternative political project. Eventually, the public protests obtained the broad-based consent that was necessary to change the framing of the economic crisis and shift the goals and measures for handling it into a more equitable downscaling direction. This is not to say that a fundamental socio-economic paradigm shift actually took place in Iceland. Rather, we see Iceland's situation as a turn within the present paradigm. In the end, the economic restructuring process in Iceland included several elements of equitable downscaling, which was not the case in Latvia. This finding sheds light on the importance of how a crisis is framed by actors with enough social power to influence the course of events.

Finally, the one factor that differentiates the two cases most clearly is the possibility of the public gaining influence over the framing of the crisis and the political agenda. In practice, this factor illustrates the link between the policy, politics and polity dimensions. In the case of Iceland, the way in which broad public opinion was able to reframe the conception of the crisis was particularly important, along with citizens' use of existing democratic institutions such as public referendums to gain power over crisis-management strategies and policy content. The Icelandic example is an interesting illustration of the transformational power that can reside in existing institutions that may 
not be perceived as radical or transition-oriented. This is an important issue that should be explored further in continued research on degrowth transitions.

Author Contributions: $\AA . N$. is the main author of this text and held the main responsibility for the draft preparation, including conceptualization, methodology, analysis and writing. K.I. assisted Å.N. closely throughout the whole process. K.I., A.F. and P.S. were all involved in the early design and outline of the study, including conceptual and empirical work. M.S. contributed specifically with the compilation of economic data and statistics for the two cases. All writers contributed to reviewing and editing the final version of the manuscript.

Funding: This research was carried out within the project "Beyond GDP-Growth: Scenarios for Sustainable Communities" funded by the Swedish Research Council for Environment, Agricultural Sciences and Spatial Planning (Formas), Grant number 2013-1842.

Acknowledgments: The authors want to thank Pernilla Hagbert for valuable input to the manuscript.

Conflicts of Interest: The authors declare no conflicts of interest. The funders had no role in the design of the study; in the collection, analysis or interpretation of data; in the writing of the manuscript; or in the decision to publish the results.

\section{References}

1. Rockström, J.; Steffen, W.; Noone, K.; Persson, Å.; Chapin Iii, F.S.; Lambin, E.F.; Lenton, T.M.; Scheffer, M.; Folke, C.; Schellnhuber, H.J.; et al. A safe operating space for humanity. Nature 2009, 461, 472. [CrossRef] [PubMed]

2. Raworth, K. A safe and just space for humanity. Can we live within the doughnut? Oxfam Policy Pract. Clim. Chang. Resil. 2012, 8, 1-26.

3. Demaria, F.; Schneider, F.; Sekulova, F.; Martinez-Alier, J. What is degrowth? from an activist slogan to a social movement. Environ. Values 2013, 22, 191-215. [CrossRef]

4. Kallis, G. In defence of degrowth. Ecol. Econ. 2011, 70, 873-880. [CrossRef]

5. D'Alisa, G.; Demaria, F.; Kallis, G. Degrowth: A Vocabulary for a New Era; Routledge: Abingdon, UK, 2014.

6. Shove, E.; Walker, G. Governing transitions in the sustainability of everyday life. Res. Policy 2010, 39, 471-476. [CrossRef]

7. Geels, F.W. The multi-level perspective on sustainability transitions: Responses to seven criticisms. Environ. Innov. Soc. Transmit. 2011, 1, 24-40. [CrossRef]

8. Swyngedouw, E. Impossible 'sustainability'and the postpolitical condition. In The Sustainable Development Paradox: Urban Political Economy in the United States and Europe; The Guilford Press: New York, NY, USA; London, UK, 2007; Volume 1, p. 20.

9. Latouche, S. Degrowth. Editorial. J. Clean. Prod. 2010, 18, 519-522. [CrossRef]

10. Schneider, F.; Kallis, G.; Martinez-Alier, J. Crisis or opportunity? Economic degrowth for social equity and ecological sustainability. Introduction to this special issue. J. Clean. Prod. 2010, 18, 511-518. [CrossRef]

11. Victor, P.A. Growth, degrowth and climate change: A scenario analysis. Ecol. Econ. 2012, 84, 206-212. [CrossRef]

12. Koch, M. Climate change, capitalism and degrowth trajectories to a global steady-state economy. Int. Crit. Thought 2015, 5, 439-452. [CrossRef]

13. Martínez-Alier, J.; Pascual, U.; Vivien, F.-D.; Zaccai, E. Sustainable de-growth: Mapping the context, criticisms and future prospects of an emergent paradigm. Ecol. Econ. 2010, 69, 1741-1747. [CrossRef]

14. Drews, S.; Antal, M. Degrowth: A "missile word" that backfires? Ecol. Econ. 2016, 126, 182-187. [CrossRef]

15. Bradley, K. Bike Kitchens-Spaces for convivial tools. J. Clean. Prod. 2016. [CrossRef]

16. Bloemmen, M.; Bobulescu, R.; Le, N.T.; Vitari, C. Microeconomic degrowth: The case of Community Supported Agriculture. Ecol. Econ. 2015, 112, 110-115. [CrossRef]

17. Hornborg, A. How to turn an ocean liner: A proposal for voluntary degrowth by redesigning money for sustainability, justice, and resilience. J. Polit. Ecol. 2017, 24, 623-632. [CrossRef]

18. Van den Bergh, J.C.J.M.; Kallis, G. Growth, A-Growth or Degrowth to Stay within Planetary Boundaries? J. Econ. Issues 2012, 46, 909-920. [CrossRef]

19. Klitgaard, K.A.; Krall, L. Ecological economics, degrowth, and institutional change. Ecol. Econ. 2012, 84, 247-253. [CrossRef]

20. Buch-Hansen, H. Capitalist diversity and de-growth trajectories to steady-state economies. Ecol. Econ. 2014, 106, 167-173. [CrossRef] 
21. Buch-Hansen, H. The Prerequisites for a Degrowth Paradigm Shift: Insights from Critical Political Economy. Ecol. Econ. 2018, 146, 157-163. [CrossRef]

22. Fritz, M.; Koch, M. Potentials for prosperity without growth: Ecological sustainability, social inclusion and the quality of life in 38 countries. Ecol. Econ. 2014, 108, 191-199. [CrossRef]

23. Joutsenvirta, M. A practice approach to the institutionalization of economic degrowth. Ecol. Econ. 2016, 128, 23-32. [CrossRef]

24. Blanchard, O.; Griffiths, M.; Gruss, B. Boom, Bust, Recovery: Forensics of the Latvia Crisis. Brook. Pap. Econ. Act. 2013, 2013, 325-388. [CrossRef]

25. Júlíusdóttir, M.; Skaptadóttir, U.D.; Karlsdóttir, A. Gendered migration in turbulent times in Iceland. Norsk Geografisk Tidsskrift 2013, 67, 266-275. [CrossRef]

26. World Bank. Online Database. Available online: http:/ / databank.worldbank.org/data/home.aspx (accessed on 15 March 2019).

27. Borowy, I. Degrowth and public health in Cuba: Lessons from the past? J. Clean. Prod. 2013, 38, 17-26. [CrossRef]

28. Bailey, D. The Environmental Paradox of the Welfare State: The Dynamics of Sustainability. New Polit. Econ. 2015, 20, 793-811. [CrossRef]

29. Fitzpatrick, T. Understanding the Environment and Social Policy; Policy Press: Bristol, UK, 2011.

30. Koch, M.; Mont, O. Sustainability and the Political Economy of Welfare; Routledge: Abingdon, UK, 2016.

31. Koch, M. Sustainable welfare, degrowth and eco-social policies in Europe. In Social Policy in the European Union: State of Play 2018; European Trade Union Institute (ETUI) and European Social Observatory (OSE): Brussels, Belgium, 2018; p. 35.

32. Büchs, M.; Koch, M. Challenges for the degrowth transition: The debate about wellbeing. Futures 2019, 105, 155-165. [CrossRef]

33. Buhr, K.; Isaksson, K.; Hagbert, P. Local Interpretations of Degrowth-Actors, Arenas and Attempts to Influence Policy. Sustainability 2018, 10, 1899. [CrossRef]

34. Lange, P.; Driessen, P.P.; Sauer, A.; Bornemann, B.; Burger, P. Governing towards sustainabilityconceptualizing modes of governance. J. Environ. Policy Plan. 2013, 15, 403-425. [CrossRef]

35. Kooiman, J. Modern Governance: New Government-Society Interactions; Sage: London, UK, 1993.

36. Héritier, A. New modes of governance in Europe: Policy-making without legislating? In Common Goods: Reinventing European and International Governance; Héritier, A., Ed.; Rowman \& Littlefield: Lanham, MD, USA, 2002; pp. 185-206.

37. Treib, O.; Bähr, H.; Falkner, G. Modes of governance: Towards a conceptual clarification. J. Eur. Public Policy 2007, 14, 1-20. [CrossRef]

38. Arnouts, R.; van der Zouwen, M.; Arts, B. Analysing governance modes and shifts-Governance arrangements in Dutch nature policy. For. Policy Econ. 2012, 16, 43-50. [CrossRef]

39. Driessen, P.P.J.; Dieperink, C.; Laerhoven, F.; Runhaar Hens, A.C.; Vermeulen, W.J.V. Towards a Conceptual Framework for The Study of Shifts in Modes of Environmental Governance-Experiences From The Netherlands. Environ. Policy Gov. 2012, 22, 143-160. [CrossRef]

40. Hall, C.M. A typology of governance and its implications for tourism policy analysis. J. Sustain. Tour. 2011, 19, 437-457. [CrossRef]

41. Hufty, M. Investigating Policy Processes: The Governance Analytical Framework (GAF). Available online: https:/ / papers.ssrn.com/sol3/papers.cfm?abstract_id=2019005 (accessed on 15 March 2019).

42. Pierre, J.; Peters, B.G. Governing Complex Societies: Trajectories and Scenarios; Palgrave MacMillan: Basingstoke, UK, 2005; pp. 1-158.

43. Bacchi, C. Analysing Policy; Pearson Higher Education AU: Frenchs Forest, Australia, 2009.

44. Palinkas, L.A.; Horwitz, S.M.; Green, C.A.; Wisdom, J.P.; Duan, N.; Hoagwood, K. Purposeful Sampling for Qualitative Data Collection and Analysis in Mixed Method Implementation Research. Adm. Policy in Ment. Health 2015, 42, 533-544. [CrossRef]

45. Flyvbjerg, B. Case study. In The Sage Handbook of Qualitative Research, Denzin, N.K., Lincoln, Y.S., Eds.; Sage Publications: Thousand Oaks, CA, USA, 2011; pp. 301-316.

46. Auers, D. Latvia. Polit. Insight 2012, 3, 12-16. [CrossRef]

47. Dovladbekova, I. Austerity Policy in Latvia and Its Consequences; Friedrich Ebert Stiftung, International Policy Analysis: Berlin, Germany, 2012. 
48. Eihmanis, E. Cherry-picking external constraints: Latvia and EU economic governance, 2008-2014. J. Eur. Public Policy 2018, 25, 231-249. [CrossRef]

49. Mezô, J.; Bagi, Á. Crisis Management in the Baltic States. In Crisis Aftermath: Economic Policy Changes in the EU and its Member States. Conference Proceedings; University of Szeged: Szeged, Hungary, 2012.

50. Hilmarsson, H.P. Managing Financial Crisis: The Case of Iceland and Latvia. Review of International Comp. Manag. 2014, 15, 200-214.

51. Dudzińska, K. The Baltic States' Success Story in Combating the Economic Crisis: Consequences for Regional Cooperation within the EU and with Russia. In PISM Policy Paper No 6; The Polish Institute of International Affairs: Warecka, Poland, 2013; Volume 54.

52. Transparency_International. Corruption Perceptions Index 2017. Available online: https://www. transparency.org/news/feature/corruption_perceptions_index_2017 (accessed on 14 June 2018).

53. Kuris, G. Outfoxing the Oligarchs in Latvia. How a tiny Baltic republic succeeded in taking its oligarchs down a peg. In Foreign Policy. 2013. Available online: https:/ foreignpolicy.com/2013/05/06/outfoxingthe-oligarchs-in-latvia / (accessed on 15 March 2019).

54. Åslund, A.; Dombrovskis, V. How Latvia Came through the Financial Crisis; Peterson Institute for International Economics: Washington, DC, USA, 2011.

55. IMF. Latvia's successful recovery not easy to replicate. In IMF Survey Magazine; International Monetary Fund, IMF, 2012; Available online: http:/ / www.imf.org/external/pubs/ft/survey/so/2012/car061112a.htm (accessed on 15 March 2019).

56. Vilks, A. Economic Crisis Management: Latvian Story. Presented at the Bank of Latvia in Riga, Ministry of Finance, Republic of Latvia. 2012. Available online: https:/ / www.slideshare.net/LatvijasBanka/economiccrisis-management-latvian-story (accessed on 15 March 2019).

57. Sommers, J.; Woolfson, C.; Juska, A. Austerity as a global prescription and lessons from the neoliberal Baltic experiment. Econ. Lab. Relat. Rev. 2014, 25, 397-416. [CrossRef]

58. Blyth, M. Austerity: The History of a Dangerous Idea; Oxford University Press: New York, NY, USA, 2013.

59. Eurobarometer. Public Opinion in the European Union National Report, Executive Summary, Latvia. Available online: http:/ / ec.europa.0eu/commfrontoffice/publicopinion/archives/eb/eb72/eb72_lv_en_exec.pdf (accessed on 15 March 2019).

60. Rasnača, Z. Constitutional change through Euro Crisis Law: Latvia; European University Institute, Department of Law, 2014. Available online: http:/ / eurocrisislaw.eui.eu/latvia/ (accessed on 15 June 2018).

61. Ungure, E.; Lulle, A. Annual Review of Labour Relations and Social Dialogue: Estonia, Latvia, Lithuania; Friedrich Ebert Stiftung, 2016; Available online: http:/ / www.fes-socialdialogue.org/news-list/e/the-2016annual-reviews-of-labour-relations-and-social-dialogue-for-16-countries-in-central-eastern-europe-andsoutheast-europe-are-online/ (accessed on 15 March 2019).

62. Higgins, A. Used to Hardship, Latvia Accepts Austerity, and Its Pain Eases. The New York Times, 1 January 2013.

63. Bideleux, R. Contrasting Responses to the International Economic Crisis of 2008-10 in the 11 CIS Countries and in the 10 Post-Communist EU Member Countries. J. Communist Stud. Transit. Polit. 2011, 27, 338-363. [CrossRef]

64. Bernburg, J.G. Economic Crisis and Mass Protest. The Pots and Pans Revolution in Iceland; Routledge: Abingdon, UK, 2016.

65. Ólafsson, S. Iceland's Financial Crisis and Level of Living Consequences; Working Paper No. 3:2011; Pjóðmálastofnun Social Research Centre, 2011. Available online: https:/ / rafhladan.is/bitstream/handle/ 10802/8057/icelands_financial_crisis_and_level_of_living.pdf?sequence=1 (accessed on 15 March 2019).

66. Wade, R.H.; Sigurgeirsdottir, S. Iceland's rise, fall, stabilisation and beyond. Camb. J. Econ. 2012, 36, 127-144. [CrossRef]

67. Loftsdóttir, K. Building on Iceland's 'Good Reputation': Icesave, Crisis and Affective National Identities. Ethnos 2016, 81, 338-363. [CrossRef]

68. Boyes, R. Meltdown Iceland: Lessons on the World Financial Crisis from a Small Bankrupt Island; Bloomsbury USA: New York, NY, USA, 2009.

69. Hallgrímsdóttir, H.K.; Brunet-Jailly, E. Contentious politics, grassroots mobilization and the Icesave dispute. Acta Sociol. 2014, 58, 79-93. [CrossRef] 
70. Goetzmann, N. Miracle à Reykjavik: Comment l'Islande s'est sortie de la crise en faisant tout l'inverse des autres. In Atlantico; 2015; Available online: http:/ / www.atlantico.fr/decryptage/miracle-reykjavikcomment-islande-est-sortie-crise-en-faisant-tout-inverse-autres-nicolas-goetzmann-2196384.html (accessed on 15 March 2019).

71. Godin, R. L'Islande tourne définitivement la page de la crise. In La Tribune; 2015. Available online: http:/ / www.latribune.fr/economie/international/1-islande-tourne-definitivement-la-page-de-lacrise-482669.html (accessed on 15 March 2019).

72. Legutko, A.J. Iceland's Financial Crisis In 2008. Political, Economic and Social Consequences. Int. Stud. Interdiscip. Polit. Cult. J. 2017, 20. [CrossRef]

73. Thorhallsson, B. The Icelandic Economic Collapse: How to Overcome Constraints Associated with Smallness? Eur. Political Sci. 2013, 12, 320-332. [CrossRef]

74. Wüthrich, W. Iceland's way out of its financial crisis. In Current Concerns; Cooperative Society Zeit-Fragen, 2015; Volume 9, Available online: https:/ / www.zeit-fragen.ch/en/numbers/2015/no-910-16-april-2015/ icelands-way-out-of-its-financial-crisis.html (accessed on 15 March 2019).

75. Curtis, K.A.; Jupille, J.; Leblang, D. I Save for Icesave: Self-Interest and Sovereign Debt Resettlement. SSRN Electron. J. 2012. [CrossRef]

76. Bowers, S. How the Icesave crisis left British deposits in limbo. Available online: https:/ /www.theguardian. com/business/2010/mar/05/icesave-crisis-savings-landsbanki (accessed on 15 March 2019).

(C) 2019 by the authors. Licensee MDPI, Basel, Switzerland. This article is an open access article distributed under the terms and conditions of the Creative Commons Attribution (CC BY) license (http://creativecommons.org/licenses/by/4.0/). 